NISA 
[To view this image, refer to the print version of this title.] 

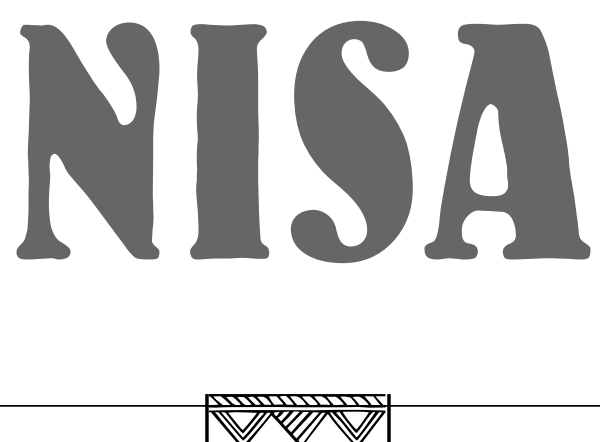

\title{
The Life and Words of a !Kung Woman
}

\author{
Marjorie Shostak
}

Harvard University Press

Cambridge, Massachusetts 
Copyright () 1981 by Marjorie Shostak All rights reserved

Printed in the United States of America

First Harvard University Press paperback edition, 2000

\section{Library of Congress Cataloging in Publication Data}

Shostak, Marjorie, 1945-

Nisa, the life and words of a !Kung woman.

Includes index.

1. Nisa. 2. !Kung (African people)—Social life and customs. 3. !Kung (African people)—Biography. I. Nisa.

II. Title.

DT797.N57S53 968.1'1004961 [B] 81-4210

ISBN 0-674-62485-8 (cloth) AAC R2

ISBN 0-674-00432-9 (pbk.)

Photographs: Marjorie Shostak/Anthro-Photo 
To Nisa and her people in the hope that their struggle to survive will be as successful in the future as it has been in the past 
